\title{
Analysis Factor of Teacher Performance Mediated by Work Motivation on Productive Teachers in Vocational School
}

\author{
Santi Susanti ${ }^{1 *}$, Sri Zulaihati ${ }^{2}$, Francaisca Elizabeth Rustiarini ${ }^{3}$, Hengki Mangiring \\ Parulian Simarmata ${ }^{4}$, Khairul Anwar ${ }^{5}$, Widaryanti ${ }^{6}$ \\ 1,2,3 Economics Education Universitas Negeri Jakarta Jakarta, Indonesia \\ ${ }^{4}$ Administrasi Perkantoran Politeknik Bisnis Indonesia, Sumut Medan, Indonesia \\ ${ }^{5}$ Department of education and teacher training, Institut Agama Islam Tebo Jambi Tebo, Indonesia. \\ ${ }^{6}$ Accounting Department, Sekolah Tinggi Ilmu Ekonomi Pelita Nusantara \\ ${ }^{*}$ Corresponding author.Email: ssusanti@unj.ac.id
}

\begin{abstract}
The purpose of this study is to see how Work Discipline and Financial Compensation affect Teacher Performance, as mediated by Work Motivation, among DKI Jakarta's productive business and management teachers. From May to June 2020, the research was carried out for two months. The survey method was employed in the study. The saturation sampling technique was used to create a pattern of 103 instructors. records on trainer performance and pay had been received from institutional information. The questionnaire become then used to gather facts on paintings subject and work motivation. The requirements analysis test, the traditional assumption test, the equation of path analysis, and the Sobel test are the data analysis techniques employed. The data used were normally distributed and linear, according to the results of the data analysis. The findings of this study suggest that work discipline and financial remuneration have a favorable and significant impact on job motivation. Then there is a favorable and considerable impact of work discipline, financial remuneration, and work motivation on teacher performance, even if only partially indicated. The Sobel test has shown that work discipline and financial reward have a considerable impact on teacher performance, which is mediated by work motivation.
\end{abstract}

Keywords: Work Discipline, Financial Compensation, Work Motivation, Teacher Performance, Path Analysis.

\section{INTRODUCTION}

The evaluation of a country's progress is seen not only through the national income aspect, but also through the quality and management aspects of its human resources. As a result, education plays a critical role in human resource implementation and development.

According to several research studies, the quality of education in Indonesia continues to lag behind that of other countries, even within ASEAN. Improving education quality is essential for improving Indonesia's education from a global perspective, and especially for the prosperity of the Indonesian nation.

The quality of good education has qualified educational components. Teachers as an important and central component are always placed as the main role in the learning process of teaching. So based on this, teacher performance is always associated with the quality of education.

Given the importance of a teacher's position as one of the primary determinants of educational quality, evaluation of its performance is required. The teacher's paintings are evaluated with the aid of deliberating the implementation of abilties owned by instructors in accordance with teachers and lecturers, Regulation No. 14 of 2005 , which states that teachers are required to have competencies-complies obtained through professional education, namely professional competency, social competence, personality competency, and pedagogic competency [1].

Individual and organizational factors, one of which is the work environment, all contribute to the improvement of teacher performance. In addition to school environment factors, good infrastructure can assist teachers in more maturely preparing learning devices and 
assisting teachers in creating learning conditions in the classroom.

Teachers are a profession, so it is natural for them to be compensated with a salary or salary as part of the recognition they deserve. Compensation, like other factors, is a motivator for teacher performance. Appropriate compensation has the potential to improve performance. Since 2015, education funds have accounted for $20 \%$ of the total state revenue and expenditure budget.

As a teacher with a noble duty and one of the mandates stated in the opening of the 1945 Constitution, it is natural that teachers are expected to perform well in order to improve the quality of national education in Indonesia. Teacher competence and performance will improve if the government, teachers, school administration, and the general public pay more attention to each element that drives teacher performance and provide advice and improvement in each element. The improved performance of teachers will be directly proportional to the nation's improved educational quality.

\section{LITERATURE REVIEW}

\subsection{Teacher Performance}

Jean and Moris [2] on Modern Educational Introduction on Teaching Foundation explain that teachers are those who make educational takes place which has been planned to direct behaviors and experiences in a person.

Kompri[4])mention that teacher's performance is a condition of a teacher who proves his proficiency in performing a behavior that the teacher exhibits during learning activities in the classroom. Priansa [2] in his book describes the performance of teachers as the output of work attainment from all efforts that teachers have made to achieve the school's goals. The performance of the teacher can be referred to through his responsibility in carrying out the duties and authority of his profession as an educator, as well as the morals he has.

Furthermore, according to Rudiana and Heryati teaching performance is the result of work done by a person or a group of people in an organization where educational goals have been established to be met through the execution of their duties and authority as educators in conducting learning activities.

Reviewed in the Peraturan Menteri Pendidikan Nasional RI No. 16 Tahun 2007, trainer competency in Indonesia is developed holistically through 4 primary competencies: pedagogical competency, personality competency, social competency, and professional competency. Teacher effectiveness is linked to the four competencies.
Based on the opinions of the aforementioned experts, the researchers used indicators of Pedagogical competency, Personality competency, Social competency, and Professional competency.

\subsection{Work Discipline}

Hasibuan [3] explained Discipline refers to an individual's willingness to follow all company policies as well as the social match stipulated within the company. Sutrisno backed up his statement [4] which explained that work discipline is adhered to existing institutional regulations in order to ensure that employees sincerely adhere to established policy.

Then according to Mangkunegara [5], Work discipline can be defined as a willingness to avoid deviant behavior in accordance with the company's prevailing social norms and ethics. Work discipline, according to Mulianto [6] is a collection of work-related provisions and regulations, as well as universal ethics, prevalence, and work-related etiquette. In the same vein, Darmawan[7] defines work discipline as a trait, conduct, and activity that conforms to the written and unwritten provisions agreed upon by a company.

Furthermore, Davis and Newstrom [8] in their book describe discipline as a management tool in instilling disciplined behavior based on institutional standards. These measures are grouped into preventable disciplines and corrective disciplines.

Dimensions of obedient work time rules, such as entry and return hours, as well as punctuality at work. Dimensions of compliance with company regulations, such as dress code, workplace behavior, and work compliance. Dimensions of adherence to workplace rules of conduct, such as work responsibilities and job suitability with the ability to.

\subsection{Financial Compensation}

Yani [9] defines financial compensation as a form of direct payment to its employees to motivate employees to have better performance. Hasibuan [3] in his book defines direct compensation as all income in the form of cash and goods obtained by employees for services they have done in the work.

According to Marnisah [10], The factors that influence the determination of compensation are Education, Experience and Dependents, Company Capabilities, Economic Circumstances, Working Conditions

Furthermore, Arifin and Fauzi [11] explain that compensation can be influenced by the following factors: government decree, market wage levels, qualifications used, worker demands The researchers used indicators of Basic salary, Allowance including Regional performance 
allowance, and Other allowance based on the opinions of several experts mentioned above.

\subsection{Work Motivation}

Mangkunegara [12] in his book describes work motivation as a condition sourced from the energy that can move an individual towards or towards achieving the organization's goals. According to Pianda [13], Work motivation is an encouragement or drive in educators to engage in activities directed at the purpose of learning, characterized by a feeling of willingness to work and readiness to meet expectations.

Similar to this opinion, Malthis and Jackson [14] in their book, work motivation is a desire within a person and driven by a particular purpose and triggers the person to act accordingly in achieving the goal.

Then Kompri [15] defines work motivation as ambition and passion in individuals driven both from internal and external factors themselves to carry out a work activity through their capabilities and competencies. According to Mamik [16] in his book, defining work motivation as an important component in the structure of personnel management development related to working achievement and leadership in the organization.

According to Wursanto [17], there are two groups of factors that influence work motivation namely, personal factors that include: (a) responsibility (b) recognition (c) the work itself (d) progress, and individual external factors consisting of (a) incentives (b) work safety (c) employment conditions (d) company discretion (e) level and supervision (f) inter-employee relations.

\subsection{Hypothesis Formulation}

The researcher developed the following research hypothesis based on the explanation of this study's conceptual description and theory:

H1: There is an influence of work discipline on work motivation.

$\mathrm{H} 2$ : There is an influence of financial compensation on work motivation.

H3: There is an influence of work discipline on teacher performance.

H4: There is an influence of financial compensation on teacher performance.

H5: There is an influence of work motivation on teacher performance.

H6: There is an influence of work discipline on teacher performance through work motivation.

H7: There is an influence of financial compensation on teacher performance through work motivation.

\section{METHOD}

This research was conducted on 103 productive business and management teachers in Central Jakarta and West Jakarta. This research was studied in 2021. Researchers looked at the problem of performance, work discipline, compensation, and work motivation on teachers.

The survey method was combined with a path analysis model in this study. For the variables of work discipline (X1) and work motivation (X2), the researcher employs primary data (Y). The secondary data from school documents is then used for the variables of teacher performance (Z) and financial compensation (X2). According to Sugiyono [18], the survey method technique is a quantitative studies technique used to obtain information from the beyond or gift about ideals, critiques, traits, behaviors, relationships, variables, and to test numerous hypotheses approximately sociological and psychological variables from samples drawn from the population unique, information series strategies with in-intensity observations (interviews or questionnaires), and studies results tend to be gen.

Bungin [19] explains that a research population is a research object in the form of humans, plants, animals, symptoms, events, and so on, and that this object will then be used as a data source. This study's affordable population consists of productive business and management teachers in public vocational high schools in Central and West Jakarta.

The researchers used saturated sampling techniques in this study. The saturated sampling is the entire reachable population or in other words, the sample taken is all parts of the affordable population.

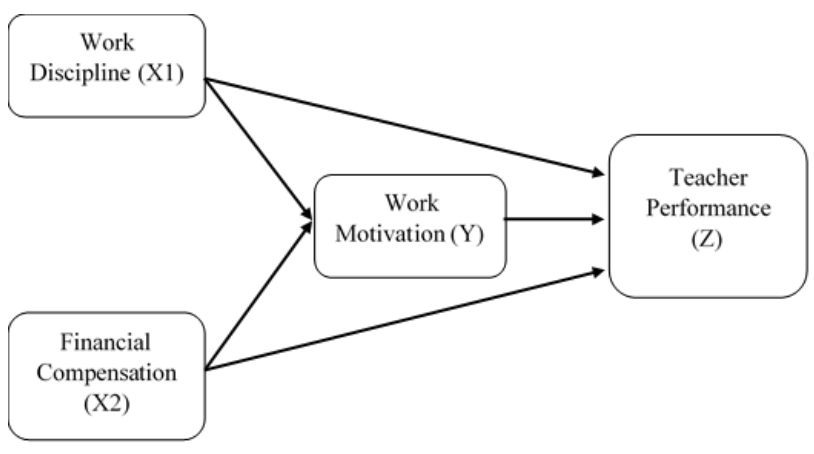

Figure 1 Research Design

This study investigates three variables: the dependent variable, the independent variable, and the mediation variable. Work discipline (X1) and financial compensation (X2) were the independent variables, teacher performance $(\mathrm{Z})$ was the dependent variable, and work motivation (Y) was the mediator. Researchers primarily collect data on work discipline (X1) and work motivation $(\mathrm{X} 2)(\mathrm{Y})$. Then there's secondary data for 
monetary compensation (X2) and teacher performance (Z).

\section{RESULT AND DISCUSSION}

The following is an explanation of the research instrument used to measure the four variables:

According to the results of the normality test using Kolmogorov-Smirnov, the data in this study are normally distributed.

Table 1 One-Sample Kolmogorov-Smirnov Test

Unstandardized Residual

\begin{tabular}{|c|c|c|}
\hline $\mathrm{N}$ & & 103 \\
\hline \multirow[t]{2}{*}{ Normal Parametersa,b } & Mean & .0000000 \\
\hline & $\begin{array}{c}\text { Std. } \\
\text { eviation }\end{array}$ & 5.92821580 \\
\hline \multirow{3}{*}{$\begin{array}{c}\text { Most } \\
\text { Differences }\end{array}$} & Absolute & .085 \\
\hline & Positive & .030 \\
\hline & Negative & -.085 \\
\hline \multicolumn{2}{|l|}{ Test Statistic } & .085 \\
\hline \multicolumn{2}{|l|}{ Asymp. Sig. (2-tailed) } & $.063 \mathrm{c}$ \\
\hline
\end{tabular}

a. Test distribution is Normal.

b. Calculated from data.

c. Lilliefors Significance Correction.

Linearity Check Based on these findings, we can deduce that all of the relationships are linear. Test for Multicollinearity Results of the Multicollinearity Test In the analysis model I, the tolerance for the independent variable is $0.575>0.1$, and the variance inflation factor between the independent variables is 1.74010 . Then, according to analysis model II, tolerance for work discipline is $0.403>0,1$, financial compensation is 0.495 $>0,1$, and work motivation is $0.385>0,1$. This model's Variance Inflation Factor results are all 10. As a result, the problem of multicollinearity was not discovered in this study. Test for Heteroscedasticity According to the results of the spearman's Rho test, the significance level in model I for work discipline (X1) is 0.823 and financial compensation is 0.935 . Work discipline is 0.346 in model II, financial compensation is 0.061 , and work motivation is 0.083 . All the significance values are above 0.05 then this study did not have a heteroskedasticity problem.

\subsection{Analysis of the Coefficient of Determination}

According to the findings of the study, the coefficient of determination for a model is 0.691 . As a result, the ability of the independent variables work discipline and financial compensation to explain the dependent variable concurrently is $69.1 \%$.

Table 2 Coefficient Determinant

\begin{tabular}{cc|c|c|c} 
Model & $\mathrm{R}$ & $\mathrm{R}$ & $\begin{array}{c}\text { Adjusted R } \\
\text { Square }\end{array}$ & $\begin{array}{c}\text { Std. Error } \\
\text { of the } \\
\text { Estimate }\end{array}$ \\
\hline 2 & $.811 \mathrm{a}$ & .691 & .683 & 1.680 \\
\hline
\end{tabular}

a. Predictors: (Constant), Work Motivation, Financial Compensation, Work Discipline

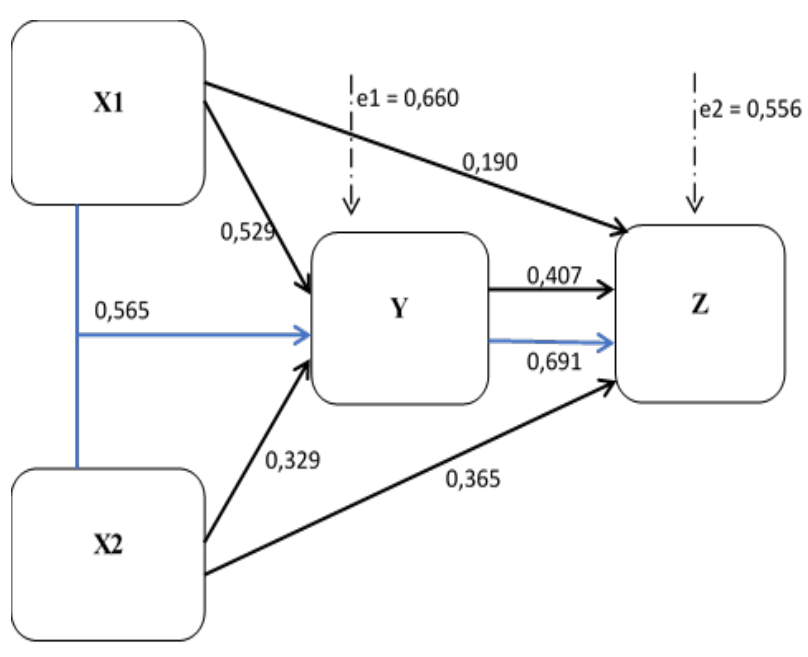

Figure 2 Path Analysis Model

Effect of Work Discipline on Work Motivation

There is a positive and significant influence between work discipline on teacher performance mediated by work motivation with total direct and indirect contribution coefficients are $0.190+0.215=0.405$ or $40.5 \%$.

There is a positive and significant influence between financial compensation on teacher performance mediated by work motivation with total direct and indirect contribution coefficients are $0.365+0.134=0.499$ or $49.9 \%$.

\section{Effect of Financial Compensation on Work Motivation}

Based on the linearity test deviation from the linearity result is $0.860>0.05$ so it has a linearity model. Furthermore, a t count of 4.020 and a statistical table with a significance of 0.05 , degree of freedom $=n-k-1$ or 103 $2-1=100$, and a table obtained by 1.98 were used to calculate the T-test.Thus, $\mathrm{t}$ count $>\mathrm{t}$ table, i.e. $4.020>$ 
1.98 , Ho is rejected, and the conclusion is that financial compensation has a positive and significant influence on work motivation.

\section{Effect of Work Discipline on Teacher Performance}

Based on the linearity test result, the deviation from linearity for this relationship is $0.145>0.05$, indicating that it has a linearity model. Furthermore, a $t$ count of 2.364 was obtained based on the T-test calculation, and the $t$ table could be found by the statistical table with a significance of 0.05 , degree of freedom $=n-k-1$ or 103-3$1=99$, the table obtained by 1.98 . Thus, $\mathrm{t}$ count $>\mathrm{t}$ table, i.e. $2.364>1.98$, Ho is rejected, and the conclusion is that work discipline has a positive and significant influence on teacher performance.

\section{Effect of Financial Compensation on Teacher Performance}

According to the linearity test, the deviation from the linearity result is $0.999>0.05$, indicating that it has a linearity model. similarly, the T-test become computed with at rely on 5.020 and a statistical desk with an importance of 0.05 , degree of freedom $=n-k-1$ or 103-3$1=99$, and a table obtained by 1.98 . Thus, $\mathrm{t}$ count $>\mathrm{t}$ table, $5.020>1.98$, Ho is rejected, and the conclusion is that financial compensation has a positive and significant influence on teacher performance.

\section{Effect of Work Motivation on Teacher Performance}

Based on the linearity test result, the deviation from linearity for this relation is $0.579>0.05$, indicating that it has a linearity model. In addition, the T-test was computed with a t count of 4.939 and a statistical table with a significance of 0.05 , degree of freedom $=n-k-1$ or 103-3-1 = 99, and a table obtained by 1.98. Thus, $t$ count $>\mathrm{t}$ table, 4.939 $>1.98$, Ho is rejected, and the conclusion is that work motivation has a positive and significant influence on teacher performance.

\section{Effect of Work Discipline on Teacher Performance mediated by Work Motivation}

Based on previous exposure, we can calculate the path coefficient for this relationship to be $0.529 \times 0.407$ $=0.215$. The Sobel test results show a p-value of 0.002 0.05 . Ho is rejected, and the conclusion is that work subject has a superb and giant effect on instructor performance thru paintings motivation.

\section{Work Motivation Mediates the Effect of Work Discipline on Teacher Performance.}

Based on previous exposure, we can calculate the path coefficient for this relationship to be $0.329 \times 0.407$ $=0.134$. The Sobel test results show a $\mathrm{p}$-value of 0.000 0.05 . Ho is rejected, and the conclusion is that monetary repayment has an effective and enormous impact on teacher overall performance as mediated using paintings motivation.

\section{CONCLUSION}

Work discipline has a large and positive impact on job motivation. Work motivation is significantly and positively influenced by monetary compensation. Discipline in the workplace has a significant and positive impact on teacher performance. Teacher performance is significantly and positively influenced by monetary compensation. Work motivation has a significant and beneficial effect on teacher performance.

\section{ACKNOWLEDGMENTS}

We thank the anonymous reviewers who have provided constructive suggestions for improving this article.

\section{REFERENCES}

[1] Depdiknas, "Undang-Undang Republik Indonesia Nomor 14 tentang Guru dan Doses," no. March, pp. 25-27, 2005.

[2] D. J. Priansa, Kinerja dan Profesionalisme Guru. Bandung: Alfabeta, 2014.

[3] Hasibuan, Manajemen Sumber Daya Manusia. Jakarta: PT Bumi Aksara, 2013.

[4] E. Sutrisno, Manajemen Sumber Daya Manusia. Jakarta: Kencana Prenada Media Group, 2014.

[5] A. P. Mangkunegara, Manajemen Sumber Daya Manusia Perusahaan. Bandung: PT Remaja Rosdakarya, 2011.

[6] S. Mulianto, Panduan Lengkap Supervisi Diperkaya Perspektif Syariah. Jakarta: PT Elex Media Komputindo, 2012.

[7] D. Darmawan, Prinsip-Prinsip Perilaku Organisasi. Surabaya: Pena Semesta, 2013.

[8] K. Davis and J. W. Newstorm, Perilaku dalam Organisasi. Jakarta: Erlangga, 2010.

[9] Yani, Manajemen Sumber Daya Manusia. Jakarta: Mitra Wacana Media, 2012.

[10] L. Marnisah, Hubungan Industrial dan Kompensasi: Teori dan Praktik. Yogyakarta: DeePublish, 2019.

[11] J. Arifin and A. Fauzi, Aspek Kuantitatif Sumber Daya Manusia. Jakarta: PT Elex Media Komputindo, 2017.

[12] A. P. Mangkunegara, Evaluasi Kinerja SDM. Bandung: PT Refika Aditama, 2012. 
[13] D. Pianda, Kinerja Guru. Sukabumi: CV Jejak, 2018.

[14] R. L. Malthis and J. H. Jackson, Manajemen Sumber Daya Manusia. Bandung: Salemba Empat, 2010.

[15] Kompri, Motivasi Pembelajaran: Perspektif Guru dan Siswa. Bandung: PT Remaja Rosdakarya, 2015.

[16] Mamik, Monograf Perkembangan dan Keunikan Variabel Motivasi Kinerja Kepuasan. Sidoarjo: Zifatama Publisher, 2015.

[17] I. Wursanto, Dasar-Dasar Organisasi. Yogyakarta: Andi Offset, 2011.

[18] Sugiyono, Metode Penelitian dan Pengembangan. Bandung: Alfabeta, 2016.

[19] B. Bungin, Metodologi Penelitian Sosial dan Ekonomi. Jakarta: Prenamedia Group, 2013. 